\title{
Determinants of Poverty in Mexico: A Quantile Regression Analysis
}

\author{
Jorge Garza-Rodriguez ${ }^{1,2, *}$, Gustavo A. Ayala-Diaz ${ }^{1}$, Gerardo G. Coronado-Saucedo ${ }^{1}$, Eugenio G. Garza-Garza ${ }^{1}$ \\ and Oscar Ovando-Martinez ${ }^{1}$
}

check for updates

Citation: Garza-Rodriguez, Jorge, Gustavo A. Ayala-Diaz, Gerardo G. Coronado-Saucedo, Eugenio G.

Garza-Garza, and Oscar

Ovando-Martinez. 2021

Determinants of Poverty in Mexico A Quantile Regression Analysis.

Economies 9: 60. https://doi.org/ 10.3390 /economies 9020060

Academic Editor: Ana

Jesus Lopez-Menendez

Received: 26 February 2021

Accepted: 9 April 2021

Published: 15 April 2021

Publisher's Note: MDPI stays neutral with regard to jurisdictional claims in published maps and institutional affiliations.

Copyright: (c) 2021 by the authors. Licensee MDPI, Basel, Switzerland. This article is an open access article distributed under the terms and conditions of the Creative Commons Attribution (CC BY) license (https:// creativecommons.org/licenses/by/ $4.0 /)$
1 Department of Economics, University of Monterrey, Av. Ignacio Morones Prieto 4500 Pte. Col. Jesús M. Garza, San Pedro Garza García, Nuevo León 66238, Mexico; gustavo.ayala@udem.edu (G.A.A.-D.); gerardo.coronado@udem.edu (G.G.C.-S.); eugenio.garzag@udem.edu (E.G.G.-G.); oscar.ovando@udem.edu (O.O.-M.)

2 Facultad de Economía, Universidad Autónoma de Nuevo León, Avenida Lázaro Cárdenas 4600 Ote. Fracc. Residencial Las Torres, Monterrey, Nuevo León 64930, Mexico

* Correspondence: jorge.garza@udem.edu

\begin{abstract}
Most studies on the determinants of poverty do not consider that the relative importance of each of these determinants can vary depending on the degree of poverty suffered by each group of poor people. For Mexico's case, the studies carried out so far do not contemplate this approach, even though there is wide variation in the degree of poverty among the different groups of the poor. Investigating these differences is important to design better policies for fighting poverty, which consider how each variable that explains poverty affects each group of people who suffer from poverty differently. This article examines the determinants of poverty for Mexican households. Using data from the Mexican National Household Income and Expenditure Survey (ENIGH) 2018, the study estimates a probit model and a quantile regression model to examine the extent to which the determinants of poverty vary across the poverty spectrum. The results from the probit model indicate that households with more than one member, having a female head, or speaker of an indigenous language are more likely to be poor. The results obtained in the quantile regressions indicate that there are significant differences with the results of the simple ordinary least squares model, especially for households in extreme poverty but also for the other income categories analyzed for several of the explanatory variables used in the models. Households in the categories extremely poor and deeply poor are most affected if they are in the southern region or if the household head speaks an indigenous language or is an elderly person. It is observed that achieving a higher educational level is an effective way to increase income across the poverty spectrum.
\end{abstract}

Keywords: poverty determinants; poverty spectrum; quantile regression; probit; Mexico

\section{Introduction}

Even though Mexico is an upper-middle-income country according to the World Bank classification, with a per capita income of $\$ 9946$ current dollars per year (World Bank 2020), almost half of its population (48.8\%) lives in poverty and 16.8\% live in extreme poverty, according to the national poverty lines (CONEVAL 2018). Unfortunately, these figures have practically remained without change in the last 10 years, since in 2008 the poverty rate was $49 \%$ and the extreme poverty rate was the same as it was in $2018,16.8 \%$.

Although the country has experienced moderate economic growth during the last two decades, this has not been enough to reduce poverty because of the prevailing inequitable distribution of income. Troyano and Martín (2017) note that even though Mexico and Brazil had a very similar economic growth rate between 1990 and 2013, Brazil managed to reduce its poverty rate by 26 percentage points (from $45 \%$ to $19 \%$ ), while that of Mexico only decreased by 4 percentage points (from $42 \%$ to $38 \%$ ). In population terms, these changes meant that Brazil managed to lift more than 30 million people out of poverty, 
while in Mexico, the number of poor increased by more than 2 million in that period. Cord et al. (2017) attribute this effect in the case of Mexico to an increase in inequality, which is caused by an increase in inequality in income from work. Esquivel (2015) also finds that economic growth in Mexico from 1992 onwards did not reduce poverty, while Campos Vázquez and Monroy-Gómez-Franco (2016), as well as Garza-Rodriguez (2018) and Fosu (2017), did find that economic growth has an inverse relationship with poverty in the Mexican case.

Regarding the dimensions of poverty, CONEVAL (2018) reports that $47.3 \%$ of the population does not have access to social security, $20.4 \%$ does not have access to a minimum basic food basket, $19.8 \%$ does not have access to basic services in their homes, $16.2 \%$ does not have access to health services, and $16.9 \%$ suffer from educational backwardness.

Several studies have addressed the issue of poverty and its determinants for the Mexican case (Fernández-Ramos et al. 2016; Garza-Rodríguez 2015; Garza-Rodriguez et al. 2010), but they have done so without taking into consideration that these determinants could vary according to the depth of poverty, that is, along the distribution of income among the poor. These studies have used the logistic regression method, which distinguishes only whether the household is poor or not but does not analyze the potentially different effects of each explanatory variable according to the income of the poor. To address this problem, recent studies (Habyarimana et al. 2015; Heshmati et al. 2019; Kedir and Sookram 2013; Peng et al. 2019) have used quantile regressions to investigate whether the determinants of poverty vary along the income distribution of the poor. The purpose of including a quantile regression approach in the analysis of the determinants of poverty is to allow for the possibility of differential effects of these determinants across the different quantiles of the income distribution (Peng et al. 2019). To our knowledge, there is no study that develops this analysis for the case of Mexico. Thus, this paper intends to contribute to the still scarce international literature that makes use of quantile regression to identify the main determinants of poverty along the income distribution of the poor, especially for the case of Mexico. Given the high levels of poverty prevailing in the country, it is important to identify these determinants to guide the public policies that can be adopted to combat poverty in Mexico.

The results obtained in the quantile regressions indicate that there are significant differences compared with the results of the simple ordinary least squares (OLS) model, especially for households in extreme poverty but also for the other income categories. The results obtained for the region of household location are particularly noteworthy, as it is found that the OLS model results underestimate the effects of the explanatory variables on poverty in the southern part of the country, which is precisely the area with the greatest poverty level. The same is true for households whose members speak an indigenous language. Another notable result of applying the quantile regression method is that the effect of studying at least one year of higher education on income (and therefore on poverty) is lower for households in extreme poverty than the OLS estimate. In summary, the econometric results of the quantile regression model indicate that the effects of the explanatory variables on poverty vary along the income distribution among the poor and therefore, it is necessary to consider this when designing policies to fight poverty in Mexico.

The article is organized as follows: Section 2 presents a review of the relevant literature, in which the main approaches used to analyze the determinants of poverty are discussed, as well as the most important findings both for Mexico and for other countries. Section 3 describes the database used while Section 4 describes the methodology and econometric models. The results of the analysis are presented in Section 5, and Section 6 concludes.

\section{Literature Review}

\subsection{Theoretical Perspectives on Poverty}

Research on the determinants of poverty has developed under three different categories: macro or structural level, micro or individual level, and contextual level (Peng et al. 2019). The structural level approach asserts that there are economic, social, and political 
factors that cause people to have limited opportunities and resources (Bradshaw 2007), while the micro-level approach holds that poverty can be explained by individual characteristics and behavior. Finally, the contextual level approach highlights the importance of neighborhood-level factors in explaining poverty.

\subsection{Empirical Evidence Using the Micro-Level Approach}

\subsubsection{Gender of Household Head}

Many studies have analyzed whether the gender of the head of the family is related to poverty, particularly if the fact that the head of the family is female increases the probability that the household is poor. This phenomenon, known as the feminization of poverty (Pearce 1978), can be explained by discrimination against women in the labor market but also because women tend to have less education than men, which is why they receive less income in the labor market (Garza-Rodríguez 2015). Most studies have found evidence in favor of the feminization of poverty (Biyase and Zwane 2018; Chen and Wang 2015; Iqbal et al. 2020; Ravindra Deyshappriya and Minuwanthi 2020; Teka et al. 2019). Some studies, such as that of Jiménez Pozo et al. (2006) for the case of Bolivia do not find evidence that female headship of the family increases poverty, as did (Székely 1998) for the case of Mexico. For this same country Garza-Rodríguez (2015), Serratos (2015) and FernándezRamos et al. (2016) find evidence that households headed by women are more likely to be poor.

\subsubsection{Age of Household Head}

As explained by life cycle theory, it is to be expected that an individual's income is low when he is young (because he has no work experience), increases as he gains experience, and begins to decrease when he reaches old age, due to the decrease in productivity because of a lower health stock. In this way, it is to be expected that the relationship between poverty and age is not linear, but that poverty is higher at a very young age, decreases in middle age, and then increases in old age again (Garza-Rodríguez 2015). Among the authors who have found this U-pattern are Lekobane and Seleka (2017), D'Ambrosio et al. (2011), Ravindra Deyshappriya and Minuwanthi (2020) and Rodrigues and Rueanthip (2019).

Among the empirical studies that have found an inverse relationship between the age of the head of the household and poverty are Garza-Rodríguez (2015) for Mexico, Yamada (2018) for Vietnam, Sekhampu (2013) for South Africa, Gounder (2013) for Fiji, and Datt and Jolliffe (2005) for Egypt. On the other hand, Székely (1998) for the case of Mexico, De Silva (2008) for the case of Sri Lanka, and Iqbal et al. (2020) for Punjab did not find any relationship between both variables.

\subsubsection{Marital Status of the Household Head}

Since the pioneering studies of Bane and Weiss (1980) and Bane and Ellwood (1986) as well as of Waite (1995) and White and Rogers (2000), the influence of family structure in poverty has been recognized, particularly the marital status of the head of the household. Households with a married couple tend to have less poverty because both members of the couple can participate in the labor market, or even if one of them stays at home in charge of raising the children, the other member of the couple can participate more fully in the labor market and thus have a higher income. Likewise, the household can enjoy economies of scale in the purchase of goods and services and have a greater incentive to save than a single person, as well as enjoy greater benefits from government social security (Lerman 2002). Evidence in favor of the hypothesis that being single, whether previously married or never married, increases the probability of being poor includes Cotter (2002), D'Ambrosio et al. (2011), Lekobane and Seleka (2017), and Weaver (2012). Recent evidence in this same direction is that of Peng et al. (2019), who, for the case of Hong Kong, finds that not having a partner (being single, divorced, or separated) significantly increases the probability of being poor. Chen et al. (2019) find the opposite for the case of Taiwan, since married, divorced, or separated people are more likely to be poor than unmarried people. 
On the other hand, Sekhampu (2013) and Cho and Kim (2017) find that marital status does not have a statistically significant effect on poverty.

\subsubsection{Education Level of the Household Head}

Since education increases the human capital of the individual, and this greater capital increases his productivity and income, poverty tends to be inversely related to the level of education (Garza-Rodríguez 2015). Many studies have found strong empirical evidence in favor of this hypothesis (Biyase and Zwane 2018; Islam et al. 2017; Jiménez Pozo et al. 2006; Larrea and Torres, 2006; Lekobane and Seleka 2017; Peng et al. 2019; Shapiro 2006). For the specific case of Mexico, researchers (Garza-Rodríguez 2015; Ramirez 2006; Serratos 2015; Székely 1998) found strong evidence in the sense that a higher level of education of the head of the household decreases the probability that the household is poor.

\subsubsection{Household Size}

From the pioneering study of Lanjouw and Ravallion (1995), it is known that household size tends to be positively correlated with poverty. The absence of adequate social security systems and low savings in developing countries tends to increase the fertility rate, which causes large household sizes with more children, increasing the dependency burden and poverty (Garza-Rodríguez 2015). Many researchers (Artha and Dartanto 2018; Gounder 2013; Lekobane and Seleka 2017; Ogutu and Qaim 2019; Ravindra Deyshappriya and Minuwanthi 2020; Sekhampu 2013) have found a direct relationship between household size and poverty. For the case of Mexico specifically, Garza-Rodríguez (2015), Székely (1998), Serratos (2015), and Ramirez (2006) also found a strong association between poverty and household size.

\subsubsection{Location Region of the Household}

Perhaps one of the most valid generalizations about poverty in developing countries is that it is higher in rural areas than in urban areas (Todaro and Smith 2011). For example, according to Ramirez (2006), in Mexico, the rural poverty rate is $67 \%$, while that of urban poverty is $42 \%$. Garza-Rodríguez (2015) mentions three reasons that could explain the fact that poverty is greater in rural areas than in urban areas. First, rural areas are characterized by relying heavily on agriculture, which in developing countries is characterized by low productivity and therefore low incomes. Second, government policies have generally been biased in favor of urban areas and against the countryside and, finally, rural areas are more susceptible to being affected by natural disasters that affect these areas not only in the short term but also in the long term by reducing their stock of capital. Gounder (2013) mentions that the lack of remunerative employment opportunities, infrastructure, and quality services also contribute to higher poverty levels in rural areas.

In line with this reasoning, many studies have found that poverty is higher in the countryside and backward regions than in the city and in prosperous regions. Lekobane and Seleka (2017) found that in Botswana, households that resided in urban areas were $8.2 \%$ less likely to be poor than those that resided in rural areas. Biyase and Zwane ( 2018) and Ravindra Deyshappriya and Minuwanthi (2020) also find that living in rural areas increases the probability of being poor in the cases of Sri Lanka and South Africa, respectively. In Guatemala, living in an urban area reduces the probability of being poor by 20\% (Shapiro 2006). In the case of Mexico Garza-Rodríguez (2015), Serratos (2015), Székely (1998), and Ramirez (2006) also find that living in rural areas increases the probability of being poor.

\subsubsection{Ethnicity}

Belonging to certain ethnic groups is a variable that in many countries is usually associated with higher levels of poverty. This may be due to historical, economic, political, and social factors that impact the income and asset-generating opportunities of these vulnerable 
groups. This effect has been widely documented in the literature (Canelas and Salazar 2014; De Silva 2008; Jayathilaka et al. 2016; Ravindra Deyshappriya and Minuwanthi 2020).

For the specific case of Mexico, González de Alba (2010) estimates that 73\% of the indigenous population is poor, which is a figure much higher than the $44 \%$ for the general population. Canedo (2018) estimates that $81 \%$ of the indigenous population residing in rural areas suffers from multidimensional poverty. Ramirez (2006) estimates that living in a locality where more than half of its population is indigenous increases the probability of being poor by $30 \%$, having the largest impact on poverty of all the variables considered in his model.

\subsubsection{Occupational Position of the Household Head}

The occupational position of the household head has a high correlation with poverty because positions that require low amounts of capital, be it physical or human, will tend to be associated with low earnings and therefore with high poverty rates (Garza-Rodríguez 2015). This author finds that working in agriculture or being self-employed increases the probability of being poor. In the case of Ecuador, Canelas and Salazar (2014) find that the probability of being poor is lower for managers, professionals, and technicians, compared to agricultural workers. A similar result is obtained by Larrea and Torres (2006) for this same country, with positive coefficients in its logistic regression model for the variables of agricultural worker and unskilled worker.

\subsubsection{Sector of Occupation of the Household Head}

The sector of occupation of the household's head is important as an explanatory variable of poverty, since it is generally related to productivity and income. The secondary sector is characterized by higher productivity and income, while the primary sector and the service sector (in developing countries) are characterized by lower productivity in such a way that a higher incidence of poverty is to be expected for households whose head works in the primary sector (Garza-Rodríguez 2015). Canelas and Salazar (2014) found for the case of Ecuador that if the household's head works in the agricultural or mining sectors, the probability of being poor increases, while working in manufacturing or commerce had no statistically significant effect. The same result regarding working in the agricultural sector was found by Shapiro (2006) for Ecuador and by Jiménez Pozo et al. (2006) for Bolivia. For Mexico, Serratos (2015) found that working in the primary sector of the economy is associated with a greater probability of living in poverty.

\subsection{Empirical Evidence Using the Quantile Regression Approach}

For the case of Sri Lanka, De Silva (2008) uses per capita consumption as the dependent variable in a quantile regression. Household head sex, education, age, and employment status are among the key factors that explain poverty. Similarly, Kedir and Sookram (2013) use the same model for Trinidad and Tobago, finding that the poverty level is greater than past measurements. The authors discovered a more significant relationship between poverty and household overcrowding for the lowest quantiles.

Research for Rwanda (Habyarimana et al. 2015) and Hong Kong (Peng et al. 2019) also analyze poverty through the use of a quantile regression model. For the case of Rwanda, the authors focused on three different quantiles: the lower $40 \%$ for the poor population, the next $40 \%$ for the middle class, and the last $20 \%$ for the non-poor. On the other hand, a ratio of income to the poverty line (I/P ratio) was applied for the Hong Kong analysis. This ratio allows the analysis of the parameters of the independent variables according to the severity of poverty.

The most relevant findings of the research on Rwanda include that the key elements to reduce poverty are education and urbanization (Habyarimana et al. 2015). For Hong Kong, the authors found that the main determinants of poverty are age, marital status, and the educational level of the household head (Peng et al. 2019). 
For the analysis of poverty determinants in India, Heshmati et al. (2019) used household monthly per capita consumption as the dependent variable, and household head's age, marital status, occupation, and education, among other sociodemographic variables, as possible determinants of poverty. One of the findings was the household head age's inverse U-shape effect on consumption levels. These effects become stronger as poverty severity decreases, from the lowest quantiles to the highest quantiles.

In summary, most of the literature on the determinants of poverty has used logistic regression to analyze this phenomenon. The variables for which more evidence has been found as significant to explain poverty have been the age, gender, and education of the household's head, as well as his/her occupational position and sector of occupation. The urban/rural location of the household and the region of the country in which the household is located has also been statistically significant in most of the studies across the world, including Mexico. Another relevant variable to explain poverty in many studies and countries has been belonging to certain ethnic groups, due to historical, economic, demographic, political, and social factors that have contributed to these groups remaining in poverty. These findings from the literature guided the selection of variables to be included in the econometric models developed in this paper.

The existing studies on the determinants of poverty for the Mexican case have used regression models, which do not consider the different effects that the various variables generally used in this type of studies may have along the distribution of income among the poor. The present study will fill this gap by using quantile regression techniques and will compare the results with those found using OLS regression.

\section{Data}

The data used in this study was obtained from the Mexican National Household Income and Expenditure Survey (ENIGH) 2018. The objective of this survey is to provide a statistical overview of the behavior of the households' income and expenditures in terms of amount, origin, and distribution (Instituto Nacional de Estadística y Geografía (INEGI) 2019). The information obtained presents households' occupational and sociodemographic characteristics, infrastructure, family composition, and the economic activity of the members. The survey is conducted by the Mexican National Institute of Statistics and Geography (INEGI) since 1984, with a periodicity of two years since 2006. The sample is representative at the state and national levels and comprises 87,826 households.

Total current income per capita (ICTPC, for its initials in Spanish) of Mexican households was used to measure welfare and compare it to the poverty lines established by CONEVAL. The two poverty lines set by CONEVAL (CONEVAL 2019) were considered: a rural poverty line of 1941.91 MXN monthly per capita and an urban poverty line of 3001.17 MXN monthly per capita.

According to Heshmati et al. (2019), making judgments about poverty incidence across time and space, or categorizing the poor in sub-groups according to their severity, needs several substantial methodology decisions. The present paper not only takes into consideration households with an income below the poverty line but also households with income above, although close to it. An income-to-poverty ratio was calculated to include households with income of up to 1.5 times the poverty line. Thus, the poverty phenomenon is recognized as more than a simple dichotomy of poor and non-poor households, being replaced by a more complete classification that is discussed in the results section.

For the probit model, the dependent variable is dichotomous, as the result when evaluating each of the households is poor or non-poor. In contrast, for the quantile regression model, the dependent variable used will be the total current income per capita of each household. The poverty line used in the study is the one defined by CONEVAL, one for each type of locality: rural or urban.

The explanatory variables used in the models are shown in Table 1, each of them with its respective statistical summary, which includes its mean and standard deviation. Within the content of the table are variables related to the household's head, such as gender and if 
he/she belongs to a native ethnic group (dichotomous variables), the level of education, marital status, employment's position and sector, the region of location of the household and the total number of household members (categorical variables), age and age squared (continuous variables).

Table 1. Summary statistics of key variables.

\begin{tabular}{|c|c|c|}
\hline Variables & Mean & Standard Deviation \\
\hline Sex of the household head (base category: male) & 0.274 & 0.446 \\
\hline Age of the household head & 49.796 & 16.033 \\
\hline Age squared of the household head & 2736.692 & 1713.292 \\
\hline \multicolumn{3}{|l|}{ Marital status of the household head (base category: married) } \\
\hline Consensual union & 0.196 & 0.397 \\
\hline Separated & 0.088 & 0.283 \\
\hline Divorced & 0.034 & 0.182 \\
\hline Widowed & 0.112 & 0.315 \\
\hline Single & 0.075 & 0.263 \\
\hline \multicolumn{3}{|l|}{ Educational level of the household head (base category: unfinished primary school) } \\
\hline Finished primary school & 0.170 & 0.375 \\
\hline At least one year of secondary school & 0.275 & 0.447 \\
\hline At least one year of high school & 0.134 & 0.341 \\
\hline At least one year of teacher training college or technical career & 0.040 & 0.197 \\
\hline At least one year of university & 0.135 & 0.342 \\
\hline \multicolumn{3}{|l|}{ Location region of the household (base category: Central) } \\
\hline Central-North & 0.304 & 0.460 \\
\hline North & 0.232 & 0.422 \\
\hline South & 0.217 & 0.412 \\
\hline Speaks an indigenous language (base category: non-speaker of an indigenous language) & 0.083 & 0.276 \\
\hline \multicolumn{3}{|l|}{ Household size (base category: 1) } \\
\hline 2 & 0.189 & 0.392 \\
\hline 3 & 0.196 & 0.397 \\
\hline 4 & 0.221 & 0.415 \\
\hline 5 & 0.146 & 0.353 \\
\hline 6 or more & 0.131 & 0.337 \\
\hline \multicolumn{3}{|l|}{ Occupational position of the household head (base category: basic support activities) } \\
\hline Bureaucrats, directors, heads & 0.039 & 0.194 \\
\hline Professionals and technicians & 0.120 & 0.325 \\
\hline Support employees in administrative activities & 0.036 & 0.185 \\
\hline Salesman & 0.097 & 0.296 \\
\hline Employees in personal services and surveillance & 0.078 & 0.269 \\
\hline Agriculture, livestock, forestry, fishing, and hunting & 0.142 & 0.349 \\
\hline Craftsmen & 0.121 & 0.326 \\
\hline Industrial machinery operators, assemblers, and drivers & 0.115 & 0.319 \\
\hline \multicolumn{3}{|l|}{ Occupational sector of the household head (base category: primary sector) } \\
\hline Secondary sector & 0.277 & 0.447 \\
\hline Tertiary sector & 0.499 & 0.500 \\
\hline
\end{tabular}

\section{Methods and Models}

\subsection{Income Versus Consumption as a Dependent Variable to Measure Poverty}

The methodology used in existing empirical studies is diverse. Over the past decades, different economic variables have been used as dependent variables to explain the determinants of poverty, such as income (Cortés 1997; Garza-Rodríguez 2015; Peng et al. 2019; Székely 1998), consumption (De Silva 2008; Heshmati et al. 2019; Kedir and Sookram 2013), and poverty status as a dichotomous variable (Cortés 1997; Garza-Rodríguez 2015; Kedir and Sookram 2013; Peng et al. 2019; Serratos 2015; De Silva 2008; Székely 1998). According to Sen (1981), the direct method for identifying the poor consists of taking the consumption baskets of basic needs as the dependent variable. Among the advantages of using this household consumption approach is the tendency of households to underestimate their income and that, especially in regions with an important informal sector, consumption 
is the best measure for lifetime income (Kedir and Sookram 2013). In contrast, the main advantage of the income approach, as Sen (1981) argues, is that it provides a metric of numerical distances from the poverty line in terms of income short-falls. The use of consumption as a dependent variable cannot elucidate such information because it only points out the short-fall for each type of need.

\subsection{Binary Regression Models}

On the other hand, the necessity of separating the effects of each determinant or correlate is problematic for the analysis of poverty. A poverty status method might be used to split these effects using a binary model, applying the poor (1) or not poor (0) dichotomy as the dependent variable. The binary regression method (Cortés 1997; De Silva 2008; GarzaRodríguez 2015; Kedir and Sookram 2013; Peng et al. 2019; Serratos 2015; Székely 1998) is used to analyze which factors define the probability of being poor. These types of models have the advantage of eliminating the effect of atypical values in the distribution of the dependent variable (Kedir and Sookram 2013).

A probit model was estimated to identify the variables that have a significant effect on the probability of being poor. The probit model (Gujarati and Porter 2009) is used to analyze the behavior of a dichotomous dependent variable. It is a model to perform regressions with binary results, which estimates the probability that the dependent variable is one of the two possible values.

Thus, $P(y=1 \mid x)=E(y \mid x)$, the probability that the value of the dependent variable is 1 is given by the vector of independent variables. Furthermore, the mathematical expression of the probit $P(y=1 \mid x)=\beta_{0}+\beta_{i} x_{i}$ shows that it consists of a constant $\beta_{0}$ and a parameter for each explanatory variable $x_{i}$.

To apply the probit model in this study, a value of 1 was assigned to household total current income per capita below the rural or urban poverty line calculated by CONEVAL (depending on the household location), and a value of 0 on the contrary. Therefore, we obtain a dependent dichotomous variable: poor households (1) and non-poor households (0).

The explanatory variables chosen for the probit model were household head's sex, age, and age squared, marital status, educational level, occupational position, occupational sector, speaking an indigenous language, region, and household size.

\subsection{The Quantile Regression Model}

The quantile regression model (Koenker and Bassett 1978) is another approach used to understand the determinants of poverty. This model allows the analysis of the effect of poverty determinants in the different quantiles in the distribution of the dependent variable, thus showing the full picture of the relationships between variables (Habyarimana et al. 2015). Additionally, this method avoids the use of constant parameters in the whole distribution (De Silva 2008) and can determine the existence of asymmetric effects in household's well-being (Kedir and Sookram 2013). Then, the differential effects of the determinants of poverty across its spectrum can be compared (Peng et al. 2019).

While a regression by the OLS method estimates how the independent variables are related to the average value of the dependent variable, quantile regression allows the study of the impact of predictive variables on different quantiles of the response distribution, in this case, income (Habyarimana et al. 2015). This enables us to find a better explanation of the relationship between the dependent variable and the independent variables of the model. Frequently, household poverty studies focus on the mean parameters of the regressions and do not examine the asymmetric effects of the explanatory variables on household income (Kedir and Sookram 2013). To address this problem in the case of Mexico, the quantile regression model was used.

To explain the quantile regression model methodology, it will be contrasted with the OLS regression, which was also estimated for comparing results (Leeds 2014). The OLS regression model can be expressed as follows:

$$
y_{i}=\beta_{0}+\beta_{i} x_{i}+\varepsilon_{i}
$$


for $i=1, \ldots, \mathrm{n}$. Where $y_{i}$ is the natural logarithm of ICTPC, $x_{i}$ is a vector of household characteristics and a non-linear function for age (see Table 1 for the list of the characteristic explanatory variables), $\beta_{i}$ is the vector of unknown coefficients to be estimated, and $\varepsilon_{i}$ is a disturbance term. In this model, the method for obtaining the parameters is by using the minimization of squared errors:

$$
\min \sum_{i}\left(y_{i}-\left(\beta_{0}+\beta_{i} x_{i}\right)\right)^{2} .
$$

Meanwhile, the quantile regression model can be expressed as follows:

$$
y_{i}=\beta_{0}^{(\tau)}+\beta_{i}^{(\tau)} x_{i}+\varepsilon_{i}^{(\tau)}
$$

where $\tau$ represents the quantile and $0<\tau<1$, for $i=1, \ldots, n$.

The quantile regression model estimates the coefficients by minimizing the weighted sum of absolute residuals of the estimation, which can be expressed as follows:

$$
\min \sum_{i=1}^{n} d_{\tau}\left(y_{i}, \hat{y}_{i}\right)=\tau \sum_{y_{i} \geq \beta_{0}^{(\tau)}+\beta_{i}^{(\tau)} x_{i}}\left|y_{i}-\beta_{0}^{(\tau)}-\beta_{i}^{(\tau)} x_{i}\right|+(1-\tau) \sum_{y_{i}<\beta_{0}^{(\tau)}+\beta_{i}^{(\tau)} x_{i}}\left|y_{i}-\beta_{0}^{(\tau)}-\beta_{i}^{(\tau)} x_{i}\right|
$$

Hao and Naiman (2007) observe that quantile regression is a natural extension of the linear regression model and is particularly useful when the researcher's interest resides in the full understanding of how the response distribution is affected by the predictor variables.

The dependent variable $y_{i}$ to be used in the quantile regression model is the natural logarithm of ICTPC, while the vector of explanatory variables $x_{i}$ consists of sex, age, age squared, marital status, and educational level of the head of the household, if he/she speaks an indigenous language, and his or her occupational sector and position. The household size and its location region were also included as explanatory variables.

\section{Results}

A probit model was estimated to identify the variables that influence the probability of a household being poor. The results are shown in Table 2. It must be pointed out that all the variables are statistically significant at a $99 \%$ confidence level, which suggests that the selected variables are important determinants of poverty in Mexico. Given that the dependent variable of the probit model denotes if a household is poor or not, the positive $(+)$ coefficients increase the probability that the household is poor, and the negative $(-)$ coefficients decrease it.

The results indicate that a household is more likely to be poor if the household head's sex is female. Barros et al. (1997) mention that male-headed households tend to have lower poverty rates than those with a female household head. If the head of the household has any marital status different from being divorced, the likelihood of the household being in poverty is greater. If the household is in the southern region of the country, there is a greater probability that the household will be poor compared to living in the central region. If the head of the household speaks an indigenous language, the probability of the household being poor also increases. When studying ethnicity through this model, Kedir and Sookram (2013) found the same result for the case of Trinidad and Tobago, suggesting that this could be caused by past failed public policies. Likewise, the results show that if the size of the household differs from one, there is a greater probability that the household will be poor. The above is consistent with the findings made by Grootaert and Narayan (2004), Lanjouw and Ravallion (1995), Lipton and Ravallion (1995), and Garza-Rodríguez (2015), who find that larger household size is positively related to the probability of being poor. 
Table 2. Results of the probit model.

\begin{tabular}{|c|c|}
\hline Explanatory Variables & \\
\hline Sex of the household head (base category: male) & $0.065(0.001)^{* * *}$ \\
\hline Age of the household head & $-0.037(0.000)^{* * *}$ \\
\hline Age squared of the household head & $0.0003(0.000)^{* * *}$ \\
\hline \multicolumn{2}{|l|}{ Marital status of the household head (base category: married) } \\
\hline Consensual union & $0.137(0.001)^{* * *}$ \\
\hline Separated & $0.072(0.001)^{* * *}$ \\
\hline Divorced & $-0.021(0.002) * * *$ \\
\hline Widowed & $0.023(0.001)^{* * *}$ \\
\hline Single & $0.020(0.001)^{* * *}$ \\
\hline \multicolumn{2}{|l|}{ Educational level of the household head (base category: unfinished primary school) } \\
\hline Finished primary school & $-0.173(0.001) * * *$ \\
\hline At least one year of secondary school & $-0.279(0.001)^{* * *}$ \\
\hline At least one year of high school & $-0.504(0.001)^{* * *}$ \\
\hline At least one year of teacher training college or technical career & $-0.612(0.002)^{* * *}$ \\
\hline At least one year of university & $-1.095(0.001)^{* * *}$ \\
\hline \multicolumn{2}{|l|}{ Location region of the household (base category: Central) } \\
\hline Central-North & $-0.301(0.001)^{* * *}$ \\
\hline North & $-0.412(0.001) * * *$ \\
\hline South & $0.214(0.001)^{* * *}$ \\
\hline Speaks an indigenous language (base category: non-speaker of an indigenous language) & $0.266(0.001)^{* * *}$ \\
\hline \multicolumn{2}{|l|}{ Household size (base category: 1) } \\
\hline 2 & $0.365(0.001)^{* * *}$ \\
\hline 3 & $0.604(0.001)^{* * *}$ \\
\hline 4 & $0.853(0.001)^{* * *}$ \\
\hline 5 & $1.112(0.001)^{* * *}$ \\
\hline 6 or more & $1.162(0.001)^{* * *}$ \\
\hline \multicolumn{2}{|l|}{ Occupational position of the household head (base category: basic support activities) } \\
\hline Bureaucrats, directors, heads & $-0.964(0.002) * * *$ \\
\hline Professionals and technicians & $-0.529(0.001)^{* * *}$ \\
\hline Support employees in administrative activities & $-0.450(0.002)^{* * *}$ \\
\hline Salesman & $-0.195(0.001)^{* * *}$ \\
\hline Employees in personal services and surveillance & $-0.429(0.001) * * *$ \\
\hline Agriculture, livestock, forestry, fishing, and hunting & $-0.107(0.001)^{* * *}$ \\
\hline Craftsmen & $-0.146(0.001)^{* * *}$ \\
\hline Industrial machinery operators, assemblers, and drivers & $-0.367(0.001) * * *$ \\
\hline \multicolumn{2}{|l|}{ Occupational sector of the household head (base category: primary sector) } \\
\hline Secondary sector & $-0.238(0.001)^{* * *}$ \\
\hline Tertiary sector & $-0.177(0.001)^{* * *}$ \\
\hline Constant & $0.844(0.003)^{* * *}$ \\
\hline Wald X2 & $5,911,524.330$ \\
\hline Pseudo R2 & 0.1989 \\
\hline Log likelihood & $-14,901,237$ \\
\hline Observations & $27,253,381$ \\
\hline
\end{tabular}

Robust standard errors are reported in parentheses. ${ }^{* * *}$ Significant at $1 \%$.

Variables that decrease the probability of living in poverty are if the household head is divorced, holds any educational level higher than unfinished primary school, if the location region is either central-north or north, if the head is employed in any position of occupation except basic support activities, and if the occupation is in the secondary or tertiary sector. The household head's age is negatively related to the probability of being poor, reflecting the effect of experience on the income of the household head. The negative coefficient for the age squared of the household head is coherent with the life-cycle theory, which asserts that income through time has the shape of a downward parabola due to human resource capital depreciation of the worker, who takes longer to finish tasks as age increases (Hoffmann and Kassouf 2005).

Based on the methodology used by Peng et al. (2019), five quantile regression models were estimated, one for each quantile determined according to the income-to-poverty line 
ratio $(\mathrm{I} / \mathrm{P})$. In Table 3 , the classification of each of the $\mathrm{I} / \mathrm{P}$ ratios is shown, as well as the percentage they represent in the total sample.

Table 3. Income-to-poverty line ratio classification (I/P ratio).

\begin{tabular}{ccc}
\hline Classification & I/P Ratio & Sample Percentage \\
\hline Extremely poor & 0.50 or lower & $11.21 \%$ \\
Deeply poor & 0.75 or lower & $25.62 \%$ \\
At the poverty line & 1.00 or lower & $40.11 \%$ \\
Near poverty & 1.25 or lower & $52.32 \%$ \\
Marginally poor & 1.50 or lower & $61.06 \%$ \\
\hline
\end{tabular}

The results of the quantile regressions and OLS are presented in Table 4. The signs of the estimated parameters are as theoretically expected, and in general, they are in line with those found by other authors in the relevant literature, in addition to the fact that, in the great majority, they agree with the results of the probit model shown before. The OLS's parameters are presented in the last column to compare them with the results of the quantile regression. Following De Silva (2008), Figure 1 shows graphically the results of the estimated quantile regressions for each of the variables. The dotted black line shows the value of the coefficients for each of the quantile regressions, and the gray shaded area indicates the $95 \%$ confidence interval. The vertical lines indicate the I/P ratios that were applied to determine the quantiles of this study. The red solid horizontal line shows the regression coefficient value by the OLS method, with two horizontal dotted lines in the same color, which indicate the confidence interval of the regression at $95 \%$. As De Silva (2008) notes, there are significant differences between the results of the models if the parameters estimated by the quantile regression are outside the confidence intervals of the OLS regression.

If the sex of the head of the household is female, a greater effect on poverty is observed in the studied quantiles, with the deepest effect on the quantile of marginally poor households. This is consistent with the corresponding result of the probit model. The coefficient obtained from the OLS regression shows a consistent sign with the coefficients of the quantile regression; however, it is noteworthy that in households in extreme poverty, the effect of the presence of a female head of household is significantly different and less profound than with the OLS method.

Age has a positive and significant association with the standard of living of households in all studied quantiles. The sign of this result is as expected and agrees with what was found by Kedir and Henry (2010), who argue that high youth unemployment rates could be one of the causes of a greater likelihood of a household being poor when it is led by young adults. On the other hand, the negative sign of the coefficients of the age squared variable reflects that at a certain age, income (measured here by ICTPC) begins to decrease. This result is consistent with the one obtained in the probit model.

The results obtained for the variable of the marital status of the head of the household suggest that households where the head lives with his partner, is separated, or is a widower perceive a lower ICTPC in all quantiles, compared to the married ones. In the OLS regression, the status of a single or widowed head of household does not have a statistically significant effect on poverty. Instead, being separated and living with his or her partner or in a free union have significant differences between the OLS method and quantile regressions. For households in extreme poverty, the effect of being separated is underestimated by the OLS method. On the other hand, for the heads of households living with their partner or in a free union in deeply poor status, the OLS method overestimates the effect of this conjugal state. The positive values of the coefficients of being single (except in households in extreme poverty) or divorced could be attributed to supporting fewer people or receiving legal benefits of separation, respectively (Kedir and Sookram 2013). 
Table 4. Results of the quantile regression.

\begin{tabular}{|c|c|c|c|c|c|c|}
\hline \multirow{2}{*}{ Explanatory Variables } & Extremely Poor & Deeply Poor & At the Poverty Line & Near Poverty & Marginally Poor & \multirow{2}{*}{ OLS } \\
\hline & I/P Ratio $=0.5$ & I/P Ratio = 0.75 & I/P Ratio = 1 & I/P Ratio $=1.25$ & I/P Ratio = 1.5 & \\
\hline Sex of the household head (base category: male) & $-0.0113(0.000)^{* * *}$ & $-0.0282(0.000)^{* * *}$ & $-0.0193(0.000)^{* * *}$ & $-0.0297(0.000)^{* * *}$ & $-0.0519(0.000)^{* * *}$ & $-0.0404(0.013) * * *$ \\
\hline Age of the household head & $0.0232(0.000)^{* * *}$ & $0.0249(0.000)^{* * *}$ & $0.0222(0.000)^{* * *}$ & $0.0224(0.000)^{* * *}$ & $0.0232(0.000)^{* * *}$ & $0.0219(0.002)^{* * *}$ \\
\hline Age squared of the household head & $-0.0002(0.000)^{* * *}$ & $-0.0002(0.000)^{* * *}$ & $-0.0002(0.000)^{* * *}$ & $-0.0002(0.000) * * *$ & $-0.0002(0.000)^{* * *}$ & $-0.0002(0.000) * * *$ \\
\hline \multicolumn{7}{|l|}{ Marital status of the household head (base category: married) } \\
\hline Consensual union & $-0.0644(0.000)^{* * *}$ & $-0.0453(0.000)^{* * *}$ & $-0.0513(0.000)^{* * *}$ & $-0.0502(0.000)^{* * *}$ & $-0.0470(0.000)^{* * *}$ & $-0.0654(0.010)^{* * *}$ \\
\hline Separated & $-0.0786(0.000)^{* * *}$ & $-0.0370(0.001)^{* * *}$ & $-0.0405(0.000)^{* * *}$ & $-0.0406(0.000)^{* * *}$ & $-0.0257(0.001)^{* * *}$ & $-0.0386(0.017) * *$ \\
\hline Divorced & $0.0351(0.000)^{* * *}$ & $0.0689(0.000)^{* * *}$ & $0.0806(0.001)^{* * *}$ & $0.0891(0.000)^{* * *}$ & $0.0686(0.001)^{* * *}$ & $0.0589(0.026)^{* *}$ \\
\hline Widowed & $-0.0409(0.000)^{* * *}$ & $-0.0428(0.000)^{* * *}$ & $-0.0278(0.000)^{* * *}$ & $-0.0163(0.000)^{* * *}$ & $-0.0069(0.001)^{* * *}$ & $-0.0260(0.020)$ \\
\hline Single & $-0.0229(0.001)^{* * *}$ & $0.0094(0.001)^{* * *}$ & $0.0118(0.000)^{* * *}$ & $0.0062(0.000)^{* * *}$ & $0.0246(0.001)^{* * *}$ & $0.0180(0.020)$ \\
\hline \multicolumn{7}{|l|}{$\begin{array}{l}\text { Educational level of the household head (base category: } \\
\text { unfinished primary school) }\end{array}$} \\
\hline Finished primary school & $0.1458(0.000) * * *$ & $0.1394(0.001)^{* * *}$ & $0.1314(0.000) * * *$ & $0.1267(0.000) * * *$ & $0.1290(0.000) * * *$ & $0.1392(0.012) * * *$ \\
\hline At least one year of secondary school & $0.2224(0.000) * * *$ & $0.2183(0.000) * * *$ & $0.2080(0.000) * * *$ & $0.2171(0.000) * * *$ & $0.2282(0.000) * * *$ & $0.2340(0.012) * * *$ \\
\hline At least one year of high school & $0.3733(0.000)^{* * *}$ & $0.3551(0.001)^{* * *}$ & $0.3577(0.001)^{* * *}$ & $0.3582(0.000) * * *$ & $0.3695(0.000)^{* * *}$ & $0.3968(0.015)^{* * *}$ \\
\hline $\begin{array}{l}\text { At least one year of teacher training college or } \\
\text { technical career }\end{array}$ & $0.4045(0.001)^{* * *}$ & $0.4084(0.001)^{* * *}$ & $0.4146(0.001)^{* * *}$ & $0.4533(0.001) * * *$ & $0.4807(0.001) * * *$ & $0.4657(0.023) * * *$ \\
\hline At least one year of university or more & $0.7419(0.001)^{* * *}$ & $0.7504(0.001)^{* * *}$ & $0.7767(0.000)^{* * *}$ & $0.7973(0.001)^{* * *}$ & $0.8313(0.001)^{* * *}$ & $0.8575(0.018)^{* * *}$ \\
\hline Central-North & $0.0842(0.000)^{* * *}$ & $0.1186(0.000)^{* * *}$ & $0.1346(0.000)^{* * *}$ & $0.1395(0.000) * * *$ & $0.1590(0.000)^{* * *}$ & $0.1281(0.010)^{* * *}$ \\
\hline North & $0.1726(0.000) * * *$ & $0.2108(0.000)^{* * *}$ & $0.2319(0.000) * * *$ & $0.2363(0.000) * * *$ & $0.2523(0.000) * * *$ & $0.2137(0.010) * * *$ \\
\hline South & $-0.2980(0.000)^{* * *}$ & $-0.2481(0.000)^{* * *}$ & $-0.2071(0.000)^{* * *}$ & $-0.1900(0.000)^{* * *}$ & $-0.1642(0.000)^{* * *}$ & $-0.2056(0.011)^{* * *}$ \\
\hline $\begin{array}{l}\text { Speaks an indigenous language (base category: non-speaker of } \\
\text { an indigenous language) }\end{array}$ & $-0.2913(0.001)^{* * *}$ & $-0.2644(0.000)^{* * *}$ & $-0.2195(0.001)^{* * *}$ & $-0.2144(0.000)^{* * *}$ & $-0.1881(0.001)^{* * *}$ & $-0.2310(0.015)^{* * *}$ \\
\hline \multicolumn{7}{|l|}{ Household size (base category: 1 ) } \\
\hline 2 & $-0.2499(0.001)^{* * *}$ & $-0.2927(0.000)^{* * *}$ & $-0.3076(0.001)^{* * *}$ & $-0.3153(0.001)^{* * *}$ & $-0.3068(0.001)^{* * *}$ & $-0.2974(0.019)^{* * *}$ \\
\hline 3 & $-0.3890(0.001)^{* * *}$ & $-0.4725(0.001)^{* * *}$ & $-0.4859(0.001)^{* * *}$ & $-0.5062(0.001)^{* * *}$ & $-0.5070(0.001)^{* * *}$ & $-0.4849(0.019)^{* * *}$ \\
\hline 4 & $-0.5392(0.001)^{* * *}$ & $-0.6113(0.001)^{* * *}$ & $-0.6444(0.001)^{* * *}$ & $-0.6526(0.001) * * *$ & $-0.6495(0.001)^{* * *}$ & $-0.6230(0.019)^{* * *}$ \\
\hline 5 & $-0.6383(0.001)^{* * *}$ & $-0.7392(0.001)^{* * *}$ & $-0.7675(0.001)^{* * *}$ & $-0.7931(0.001)^{* * *}$ & $-0.7821(0.001)^{* * *}$ & $-0.7504(0.020) * * *$ \\
\hline 6 or more & $-0.6643(0.001)^{* * *}$ & $-0.7560(0.001)^{* * *}$ & $-0.7865(0.001)^{* * *}$ & $-0.8173(0.001)^{* * *}$ & $-0.8208(0.001)^{* * *}$ & $-0.7820(0.020) * * *$ \\
\hline
\end{tabular}


Table 4. Cont.

\section{Explanatory Variables}

\section{Extremely Poo}

I/P Ratio $=0.5$

Deeply Poor
I/P Ratio $=0.75$

At

At the Poverty Line

Near Poverty

I/P Ratio = 1

I/P Ratio = 1.25

Occupational position of the household head (base category: basic support activities)

Bureaucrats, directors, heads

Professionals and technicians

Support employees in administrative activities

Salesman

$\begin{array}{ll}0.6144(0.000)^{* * *} & 0.6474(0.000)^{* * *} \\ 0.3427(0.000)^{* * *} & 0.3448(0.001)^{* * *} \\ 0.3391(0.001)^{* * *} & 0.2724(0.000)^{* * *} \\ 0.0673(0.001)^{* * *} & 0.0894(0.000)^{* * *} \\ 0.2383(0.000)^{* * *} & 0.2463(0.001)^{* * *} \\ -0.2221(0.001)^{* * *} & -0.1657(0.001)^{* * *} \\ 0.0484(0.000)^{* * *} & 0.0835(0.000)^{* * *} \\ 0.2301(0.000)^{* * *} & 0.2035(0.000)^{* * *}\end{array}$

$0.6464(0.001)^{* * *}$ $0.3544(0.001)^{* * *}$

$0.2604(0.001)^{* * *}$

$0.1129(0.000)^{* * *}$

$0.2437(0.000)^{* * *}$

Agriculture, livestock, forestry, fishing, and hunting

Craftsmen

Industrial machinery operators, assemblers, and drivers

Occupational sector of the household head (base category:

primary sector)

$$
\begin{aligned}
& \text { Secondary sector } \\
& \text { Tertiary sector }
\end{aligned}
$$

Constant

$0.6514(0.001)^{* * *}$ $0.3537(0.000)^{* * *}$

$0.2490(0.000)^{* * *}$

$0.1181(0.000) * * *$

$0.2223(0.000)^{* * * *}$

$-0.0858(0.001)^{* * *} \quad-0.0409(0.001)^{* * *}$

$0.0996(0.000) * * *$

$0.0863(0.000) * * *$

$0.1856(0.000) * * *$

$0.0996(0.000)^{*}$

$0.2066(0.000)^{* * *}$

$\begin{array}{llllll}0.3542(0.001)^{* * *} & 0.3077(0.000)^{* * *} & 0.3203(0.000)^{* * *} & 0.3110(0.000)^{* * *} & 0.3154(0.001)^{* * *} & 0.3233(0.015)^{* * *} \\ 0.2907(0.001)^{* * *} & 0.2820(0.000)^{* * *} & 0.2923(0.000)^{* * * *} & 0.2892(0.000)^{* * *} & 0.2970(0.001)^{* * *} & 0.2912(0.014)^{* * *} \\ 6.5697(0.002)^{* * *} & 6.9141(0.002)^{* * *} & 7.1820(0.001)^{* * *} & 7.3614(0.001)^{* * *} & 7.4209(0.001)^{* * *} & 7.2784(0.045)^{* * *}\end{array}$

Robust standard errors are reported in parentheses. ${ }^{*}$ Significant at $10 \%$; ${ }^{* *}$ Significant at $5 \%$; *** significant at $1 \%$.

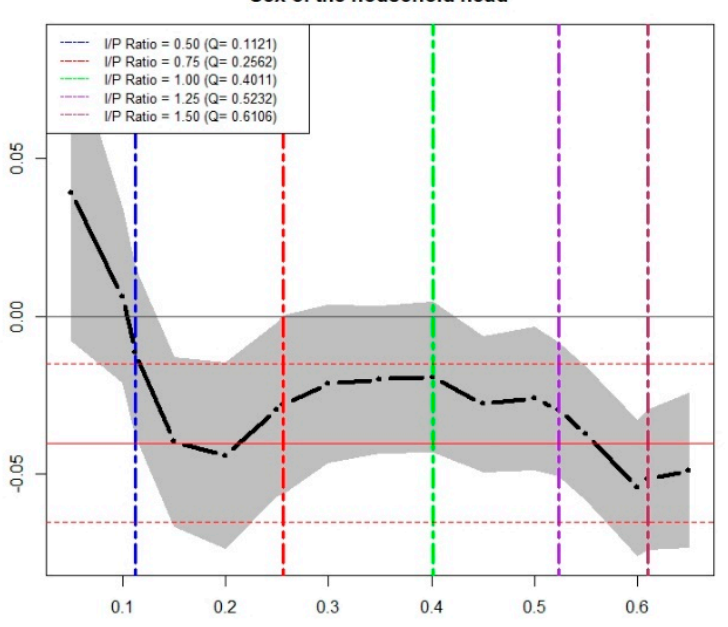

Age of the household head

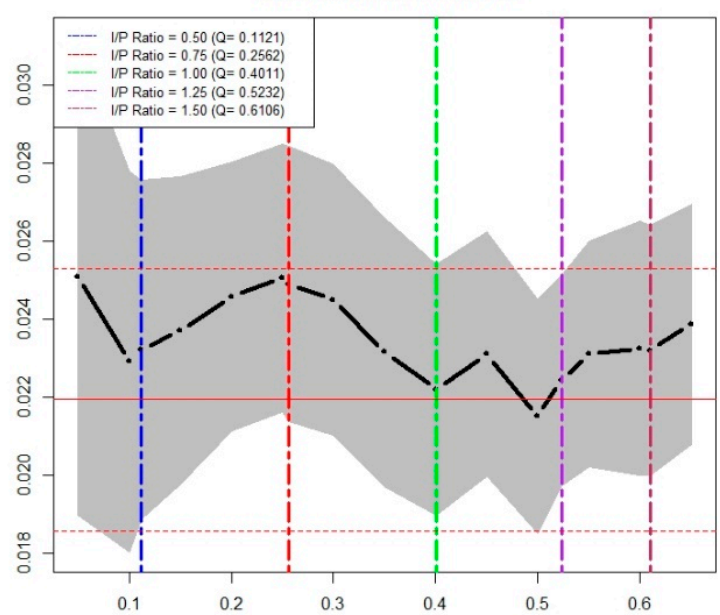

Figure 1. Cont.
Age squared of the household head

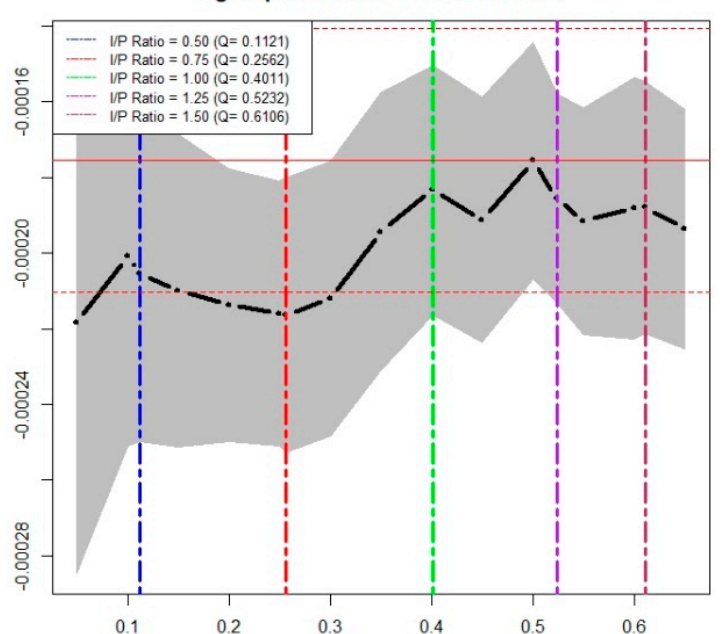

$0.7111(0.027)^{* * *}$ $0.3493(0.016)^{* * *}$ $0.2601(0.020) * * *$ $0.1264(0.016) * * *$ $0.2304(0.015) * * *$ $-0.0283(0.016)$ * $0.0808(0.014) * * *$ $0.1932(0.013) * * *$

$0.0027(0.001)^{* * *}$

$0.0928(0.000) * * *$ $0.1743(0.000)^{* * *}$ 

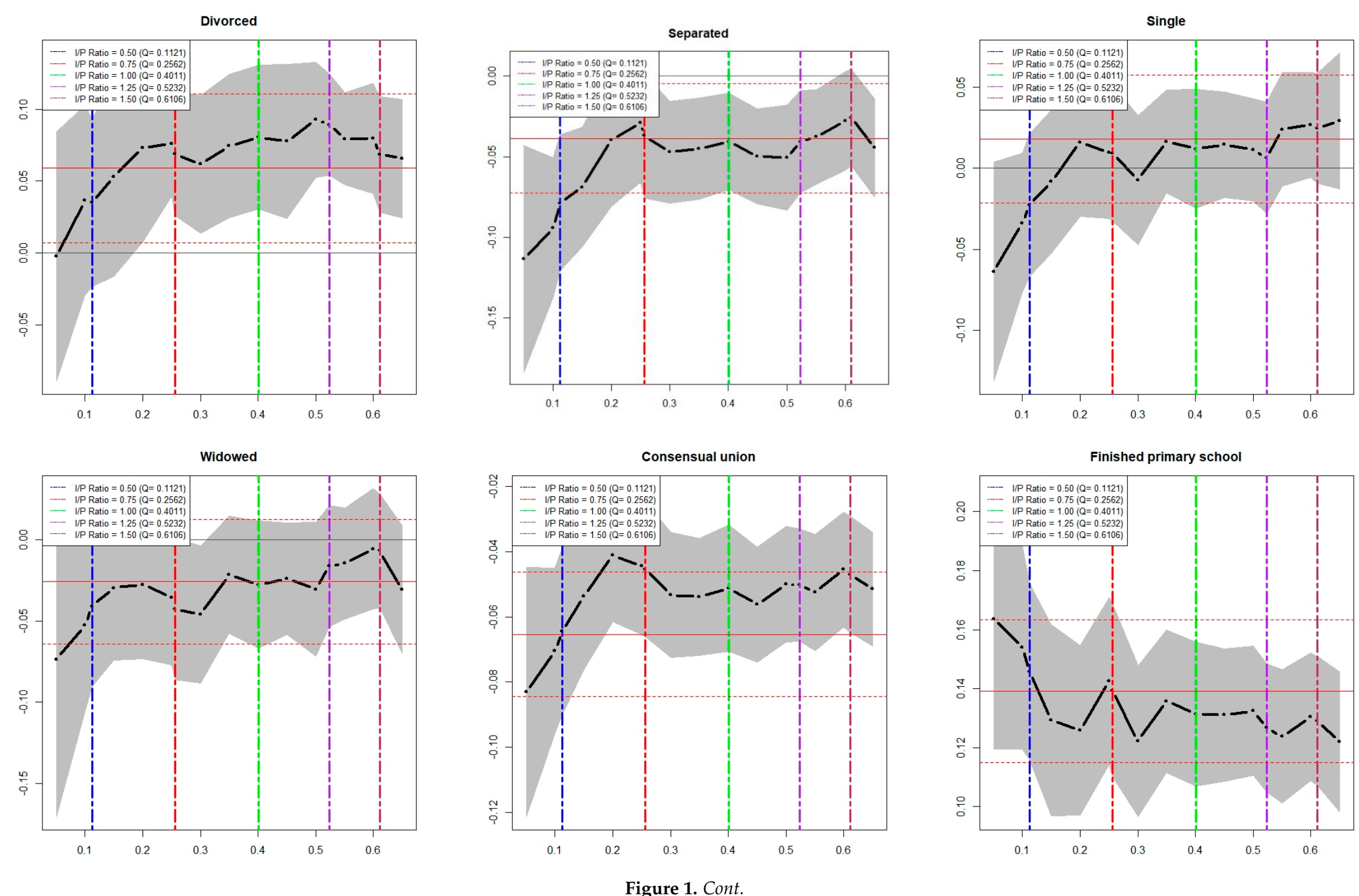

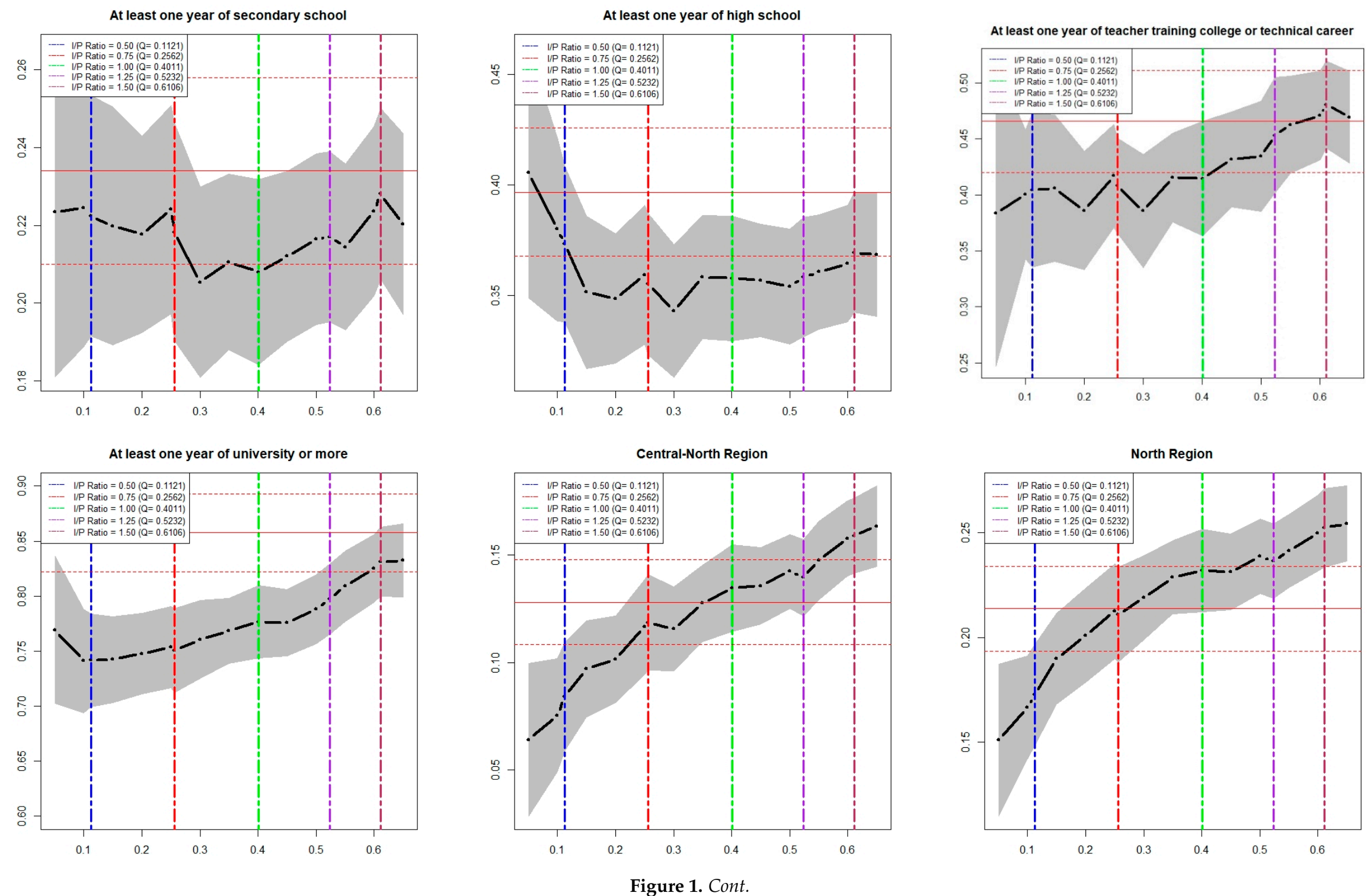
South Region

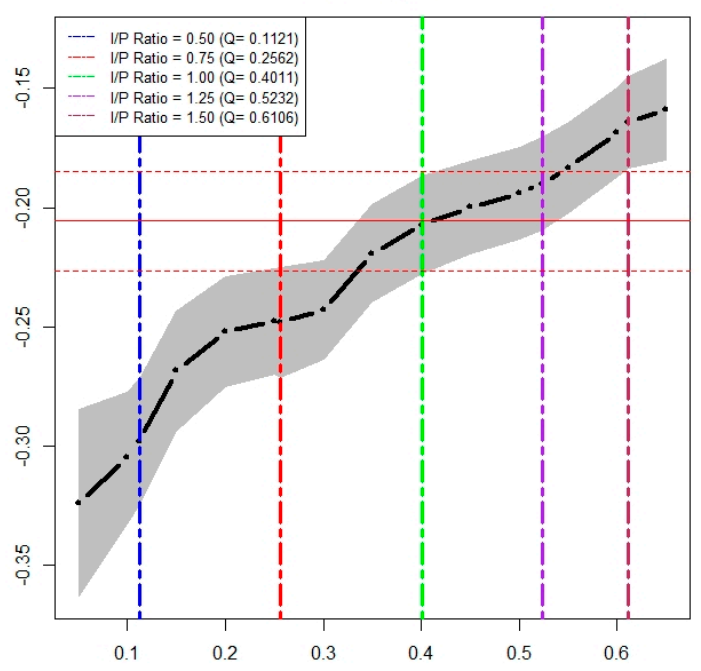

Household size: 3

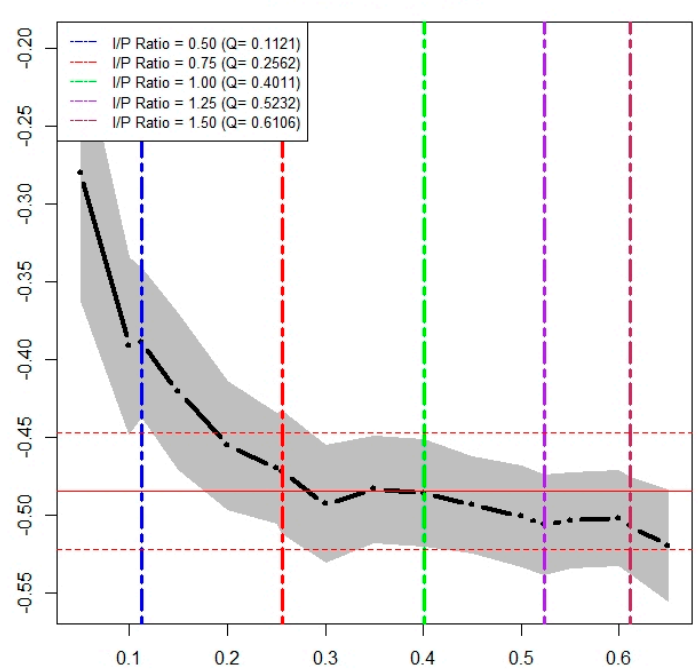

Speaks an indigenous language

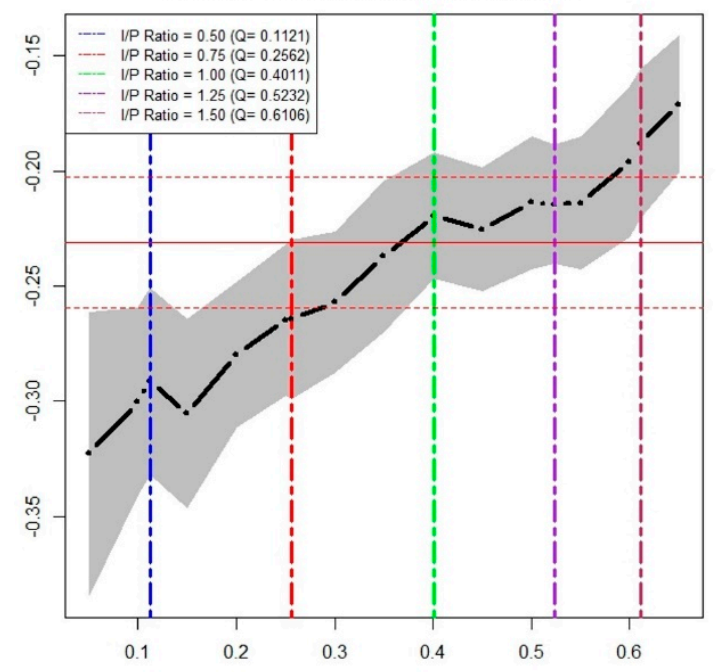

Household size: 4

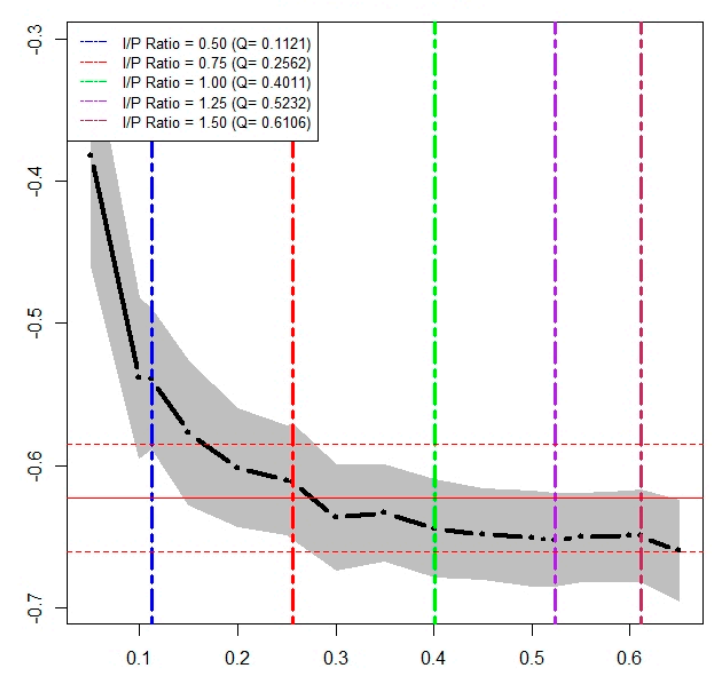

Figure 1. Cont.
Household size: 2

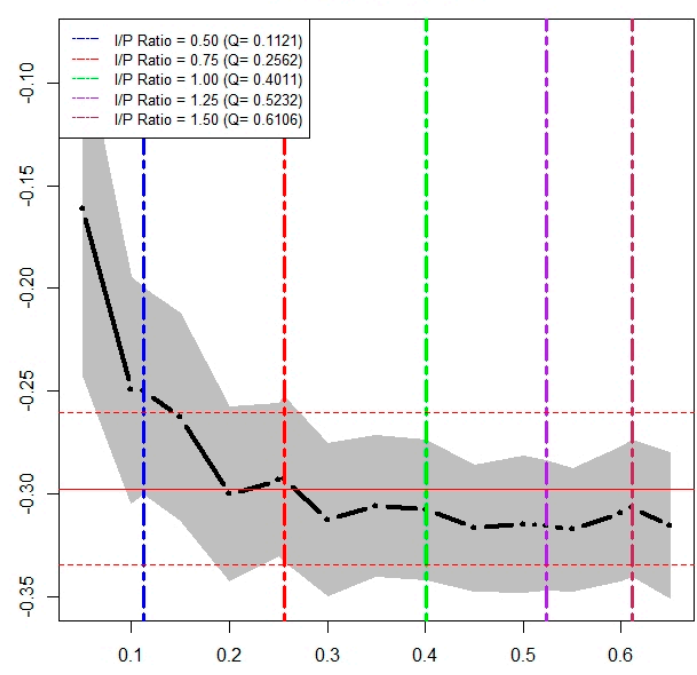

Household size: 5

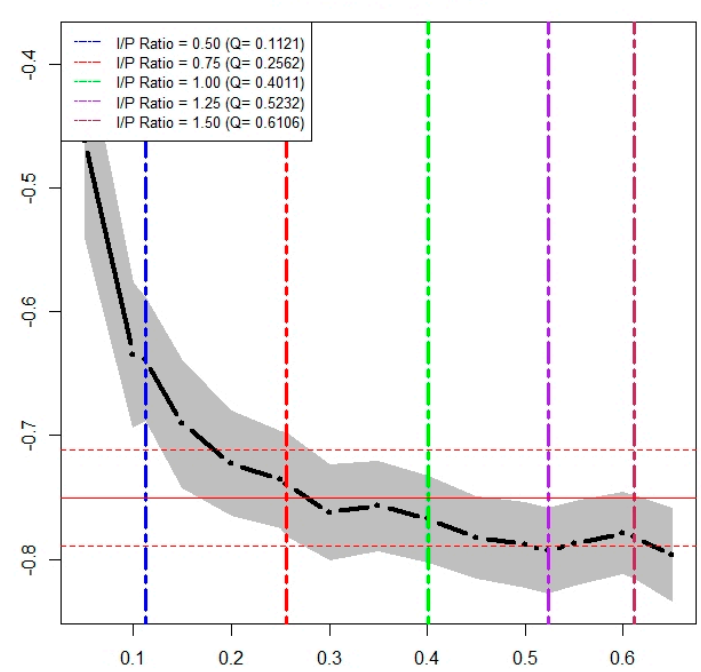



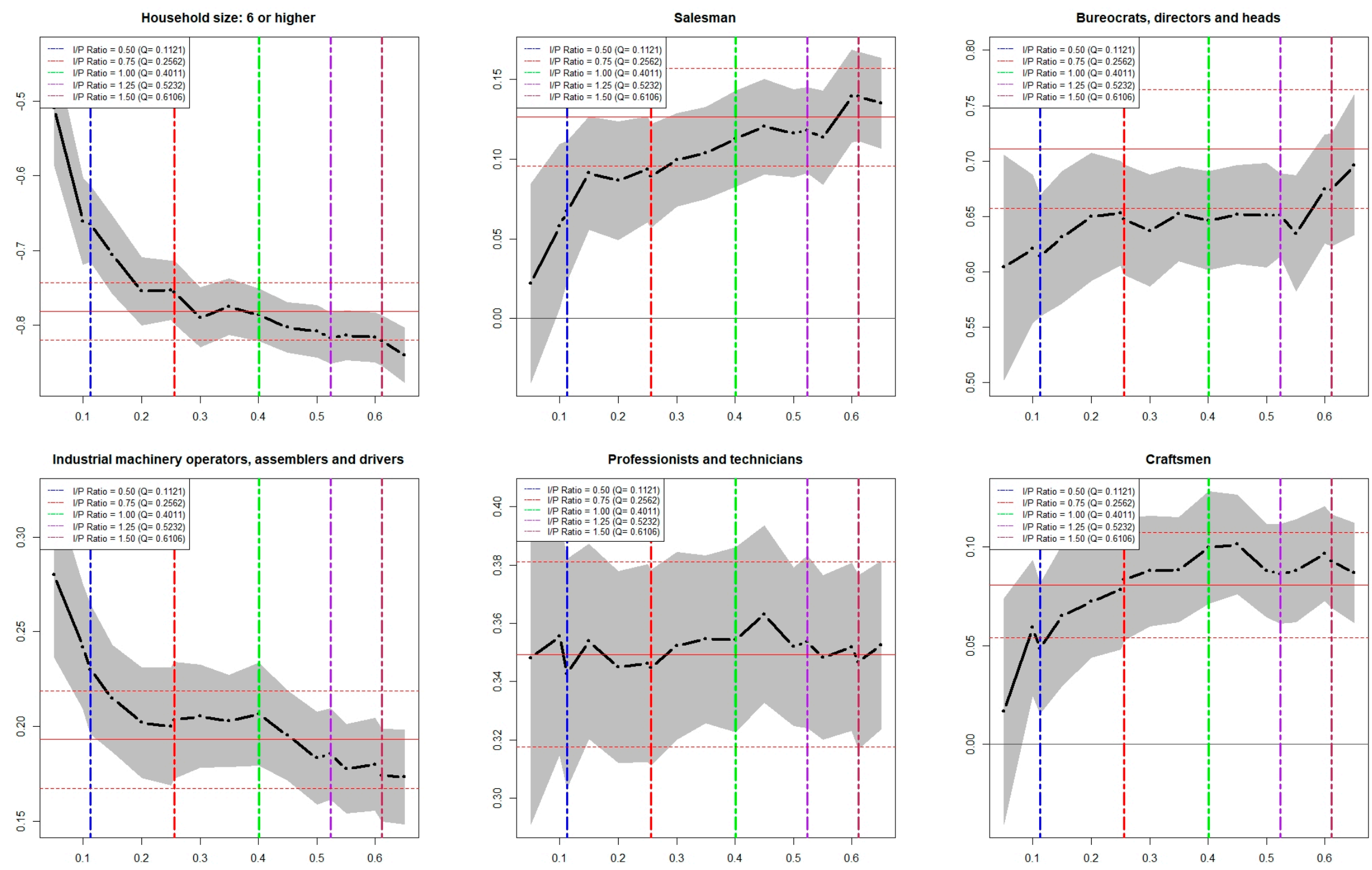

Figure 1. Cont. 

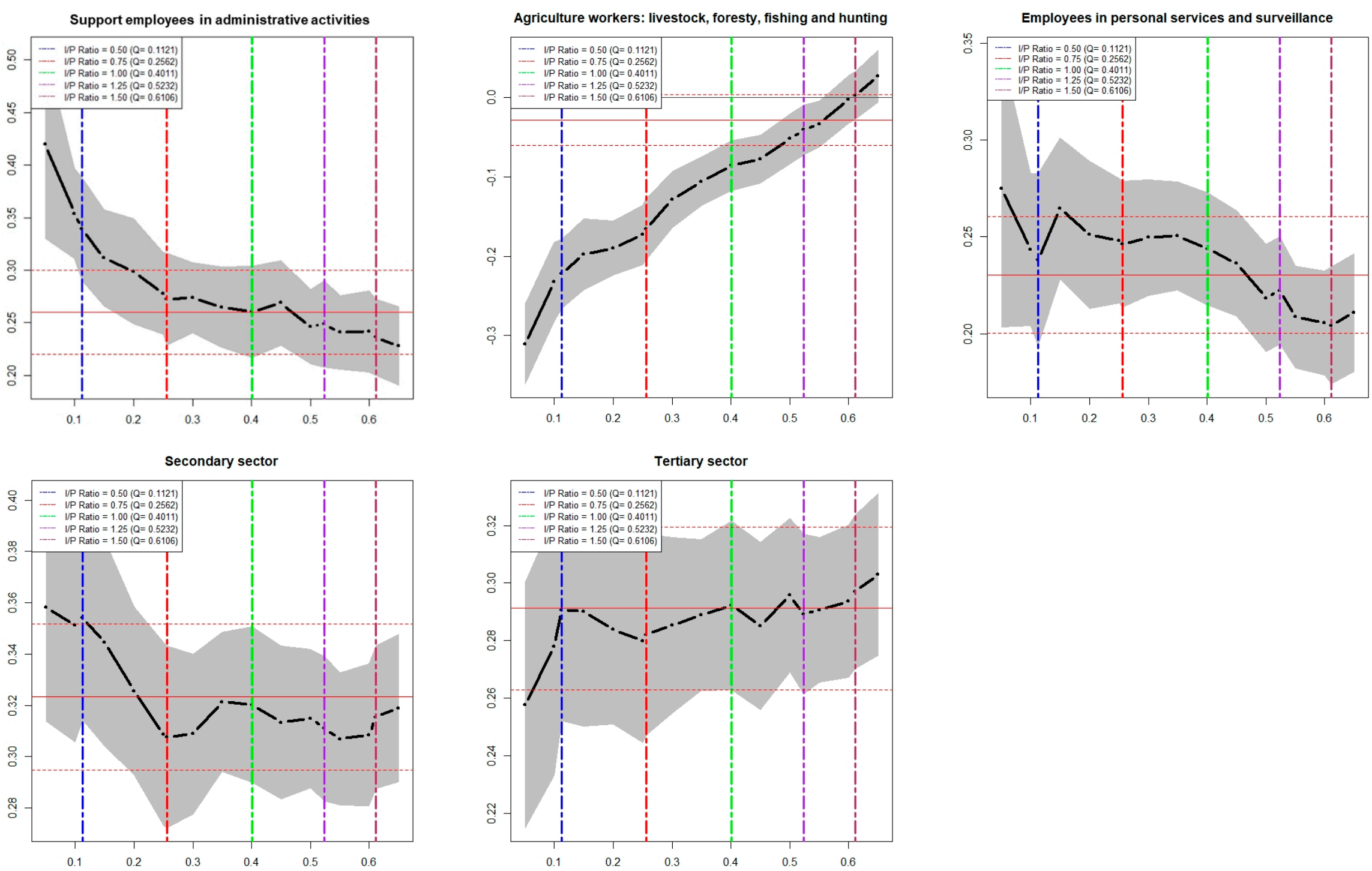

Figure 1. Quantile regression and ordinary least squares (OLS) coefficients. 
The only variable whose sign differs from the one obtained in the probit model is the single marital status. The binary model indicates that being single increases the probability that the household is poor. Cheung (2015) suggests that this could be due to factors related to participation in the labor market. Single household heads have difficulty balancing their time between being resource providers and leading the family. In contrast to the above, in the quantile regression, households that are not in extreme poverty benefit from the single status of the head of the household.

As expected, any educational level higher than unfinished primary school increases the ICTPC of households. That is, a higher education level of the head of the household significantly improves the welfare of Mexican households throughout the entire spectrum of poverty. In line with the results of the probit model, all levels of education decrease the likelihood of the household being poor. Figure 1 shows an overestimation of the results of the OLS method for household heads at the poverty line who have at least one year of secondary school. The same result is shown for households in deeply poor status, at the poverty line, and near poverty in which the heads have at least one year of high school. The same is true for those who got to study at least one year of teacher training college or technical school and whose income is below the corresponding income line, where the results of the OLS again show a more favorable condition in terms of the ICTPC than the quantile regression results. For households in extreme poverty and deeply poor status, having complete primary education or at least one year of secondary school has a greater effect on their ICTPC than in the higher quantiles. On the contrary, in marginally poor and near poverty households, having at least one year of teacher training college or technical school or at least one year of university or more has a greater effect than in the rest of the quantiles.

In terms of the region of location of the home and compared with households located in the central region, the results show strong regional patterns of lower poverty levels in the central-north and north regions and higher poverty in the south region of the country. According to Ortiz Galindo and Bolivar (2013), among the causes that have prevented the reduction of poverty is the segmentation of development in the country, since the southeast region of Mexico is the most marginalized. The situation described above may partly explain the negative coefficients in the quantile regressions and OLS for households located in the South. This result is consistent with that obtained in the probit model. In line with the results of the OLS regression, location is important for well-being, considering that the results for all quantiles are statistically significant at $99 \%$ confidence. It is interesting to observe how in the three regions, the extremes of the poverty spectrum (households in extreme poverty and marginally poor) show a difference between the OLS estimate and the quantile regression. For the central-north and north regions, first, the effect is overestimated and then underestimated, respectively. In the south region, the effect in the households in extreme poverty is underestimated, and for marginally poor households, it is overestimated. Other differences between the methods occur in households near poverty located in the north region and those in deeply poor status in the south of the country, with a smaller effect in the OLS regression than in the quantile regression.

Speaking a native ethnic group language has a negative statistically significant effect on poverty. De Alba (2017) mentions that the indigenous population is discriminated against in the labor market and that they need to work more to compensate for the low wages they receive. The OLS method underestimates the effect of this variable for households living in extreme poverty and deeply poor, while for marginally poor households, the estimate by the OLS method is greater than that found by quantile regression.

For the results of the household size variable, the coefficients are negative in any quantile and in any of the categories. It can be noticed that for households in extreme poverty, the results of the OLS regression overestimate the effect this variable has on the ICTPC. Additionally, in households near poverty and marginally poor, with five and six or more members, respectively, the results of the OLS underestimate the effect.

In terms of the occupational position of the head of the household and in comparison with the heads of household who are workers in elementary and support activities, the 
results show a positive relationship with the ICTPC for all positions except for agricultural workers in livestock, forestry, hunting, and fishing activities, in which there is a negative effect on the studied quantiles. Huesca (2009) points out that in Mexico, a large number of informal workers are employed in agricultural activities. These workers suffer an important salary gap with formal employees, who receive a higher remuneration for the work performed (Rodríguez Pérez et al. 2019). Significant differences were found between the results of the methods for households in extreme poverty, except for the occupations of professionals and technicians, and workers in personal services and surveillance. For the positions of salesmen and workers in agricultural, livestock, forestry, hunting, and fishing activities, the value of the coefficient increases as the studied quantile increases. However, in the categories of support employees in administrative activities and operators of industrial machinery and transport drivers, the effects on the ICTPC are greater and are underestimated by the OLS regression exclusively for households in extreme poverty. The coefficients estimated for officials, directors, and managers show that the OLS method overestimates the effect for all quantiles, except for the marginally poor. As for the results of the probit model, all are consistent with those of the quantile regressions, except for the heads of household employed in agricultural, livestock, forestry, hunting, and fishing activities.

Regarding the sector of occupation of the household head in comparison with households' heads working in the primary sector, the results show a positive effect in the ICTPC both for the secondary and the tertiary sectors. This result is coherent with the result obtained in the probit model, where it is shown that if a household head works in the secondary or tertiary sectors, the probability of poverty diminishes. Considering the coefficients of the quantile regressions, it can be seen that the values are higher for the secondary sector than for the tertiary sector. Coll-Hurtado and Ordóñez (2006) found that in Mexico, two contrasting realities exist in the tertiary sector: one with a high level of professionalization and another one where banal, of limited qualification, and underpaid services are predominant. Activities such as elderly care, fast food delivery, small business clerks, domestic and unprofessional hotel services are the type of activities within the tertiary sector that the members of the poorest households usually perform. For the case of the secondary sector, the effect is higher and even underestimated by the OLS in extremely poor households. The estimates obtained for the tertiary sector from the quantile regressions and from the OLS, do not show significant differences. This indicates that the positive effect on ICTPC for the households where the head works in a tertiary sector is persistent throughout the income distribution.

\section{Conclusions}

This study, the first of its kind for the case of Mexico, analyzes the determinants of poverty in five quantiles of income distribution: extremely poor, deeply poor, at the poverty line, near poverty, and marginally poor households. A probit and a quantile regression model were estimated using the ENIGH 2018 database to understand with more clarity the characteristics of the poverty spectrum in Mexico.

A probit model was applied to estimate the probability that a Mexican household finds itself in poverty given its socio-economic and demographic characteristics. It was found that among the variables related to the household head that decrease the probability for the household being poor are household head's age, divorced marital status, educational level higher than incomplete primary school, not being employed in basic support activities nor in the primary sector, and that the region where the household is located is different from the south. In contrast, the variables that increase the probability of being poor are if the household head is female, speaks an indigenous language, and if the household size is higher than one.

The quantile regression model was used to examine the correlates of poverty at different points of the income distribution. With the results obtained, it can be observed that the OLS method cannot explain adequately the situation of households in extreme 
poverty. The location region of the households shows contrasting results with households in extreme poverty and marginally poor. These are overestimated and underestimated by the OLS method, respectively. The results of the quantile regression method revealed that poverty is more severe than under the OLS estimations for households in extreme poverty and deeply poor for the south region and households with heads that are speakers of a native ethnic group language. The quantile regression results across the poverty spectrum show that achieving a higher educational level is an effective way of increasing household income. The age of the household head, if he or she is divorced or widowed, has completed primary school, if his or her position of occupation is professional or technician, personal service, or surveillance, or if he or she works in the tertiary sector, do not present significant differences between the quantile regression method and the OLS method. Households in extreme poverty have more severe needs and have higher differences between the OLS and the quantile regression coefficient estimates.

The econometric results obtained in the quantile regression analysis can be useful for the design and application of policies to combat poverty by identifying the factors that have a greater effect on each group of poor people throughout the income distribution among the poor. In addition, although they are based only on the Mexican case, the results obtained in this research showing that the effect of some of the determinants of poverty varies according to the income of the poor, add to the international literature on this topic (De Silva 2008; Habyarimana et al. 2015; Heshmati et al. 2019; Kedir and Sookram 2013; Peng et al. 2019). It is hoped that they can be used to increase the interest in carrying out more studies with the same methodology for other countries, to be able to find out with greater precision the effects of the determinants of poverty in the different groups of poor people.

The present study has several limitations. First, since the database used is a crosssection, the study does not investigate the determinants of poverty dynamics (FernándezRamos et al. 2016; Garza-Rodriguez et al. 2010). Second, also due to the cross-sectional nature of the data, the paper does not consider the important effect of economic growth on poverty levels (Garza-Rodriguez 2018). Third, the effects of anti-poverty programs implemented in the country are not considered. Finally, the effects of the so-called life events on poverty are not analyzed either (Peng et al. 2019).

For future research, it is recommended to include in the analysis the interaction between variables and investigate the evolution of poverty determinants over time through a quantile regression methodology. Another interesting issue to analyze would be to contrast the analysis using consumption instead of income as the dependent variable. Finally, as suggested by one of the reviewers, it would be interesting to consider the use of spatial regression models to capture the presence of spatial dependence and potential spatial spillovers.

Author Contributions: All authors contributed equally to the data preparation and the analysis and the interpretation of results. All authors made major contributions to writing the manuscript. All authors have read and agreed to the published version of the manuscript.

Funding: This research received no external funding.

Data Availability Statement: Publicly available datasets were analyzed in this study. This data can be found from Instituto Nacional de Estadística y Geografía (INEGI), Mexico.

Acknowledgments: The authors would like to thank four anonymous reviewers and the Academic Editor for their helpful comments on earlier versions of this paper.

Conflicts of Interest: The authors declare no conflict of interest.

\section{References}

Artha, Dwi Rani Puspa, and Teguh Dartanto. 2018. The multidimensional approach to poverty measurement in Indonesia: Measurements, determinants and its policy implications. Journal of Economic Cooperation and Development 39: 1-38.

Bane, Mary Jo, and R. S. Weiss. 1980. Alone together: The world of single-parent families. American Demographics 2: 11-15. 
Bane, Mary Jo, and David T. Ellwood. 1986. Slipping into and out of Poverty: The Dynamics of Spells. The Journal of Human Resources 21: 1-23. [CrossRef]

Barros, Ricardo, Louise Fox, and Rosane Mendonca. 1997. Female-Headed Households, Poverty, and the Welfare of Children in Urban Brazil. Economic Development and Cultural Change 45: 231-57. [CrossRef]

Biyase, Mduduzi, and Talent Zwane. 2018. An Empirical Analysis of the Determinants of Poverty and Household Welfare in South Africa. The Journal of Developing Areas 52: 115-30. [CrossRef]

Bradshaw, Ted K. 2007. Theories of Poverty and Anti-Poverty Programs in Community Development. Community Development 38: 7-25. [CrossRef]

Campos Vázquez, Raymundo M., and Luis A. Monroy-Gómez-Franco. 2016. La relación entre crecimiento económico y pobreza en México. Investigacion Economica 75: 77-113. [CrossRef]

Canedo, Ana P. 2018. Analyzing Multidimensional Poverty Estimates in Mexico From an Ethnic Perspective: A Policy Tool for Bridging the Indigenous Gap. Poverty and Public Policy 10: 543-63. [CrossRef]

Canelas, Carla, and Silvia Salazar. 2014. Gender and ethnic inequalities in LAC countries. IZA Journal of Labor and Development 3: 1-15. [CrossRef]

Chen, Ke-Mei, and Te-Mu Wang. 2015. Determinants of Poverty Status in Taiwan: A Multilevel Approach. Social Indicators Research 123: 371-89. [CrossRef]

Chen, Ke-Mein, Chao-Hsien Leu, and Te Mu Wang. 2019. Measurement and Determinants of Multidimensional Poverty: Evidence from Taiwan. Social Indicators Research 145: 459-78. [CrossRef]

Cheung, Kelvin Chi-Kin. 2015. Child Poverty in Hong Kong Single-Parent Families. Child Indicators Research 8: 517-36. [CrossRef]

Cho, Sunmee, and Taeyoon Kim. 2017. Determinants of Poverty Status in Rwanda. African Development Review 29: 337-49. [CrossRef]

Coll-Hurtado, Atlantida, and Juan Córdoba y Ordóñez. 2006. La globalización y el sector servicios en México. Investigaciones Geograficas 61: 114-31. [CrossRef]

CONEVAL. 2018. Anexo Estadístico 2018. Resultados de Pobreza En México a Nivel Nacional y Por Entidad Federativa $2008-2018$. Available online: www.coneval.org.mx/Medicion/MP/Paginas/Pobreza-2018.aspx (accessed on 14 April 2021).

CONEVAL. 2019. Evolución de las líneas de Pobreza por Ingresos. Available online: https://www.coneval.org.mx/Medicion/MP/Paginas/ Lineas-de-Pobreza-por-Ingresos.aspx (accessed on 14 April 2021).

Cord, Louise, Oscar Barriga-Cabanillas, Leonardo Lucchetti, Carlos Rodríguez-Castelán, Liliana D. Sousa, and Daniel Valderrama. 2017. Inequality Stagnation in Latin America in the Aftermath of the Global Financial Crisis. Review of Development Economics 21: 157-81. [CrossRef]

Cortés, Fernando. 1997. Determinantes de la pobreza de los hogares. México. 1992. Revista Mexicana de Sociología 59: 131-60. [CrossRef]

Cotter, David. A. 2002. Poor people in poor places: Local opportunity structures and household poverty. Rural Sociology 67: 534-55. [CrossRef]

D’Ambrosio, Conchita, Joseph Deutsch, and Jacques Silber. 2011. Multidimensional approaches to poverty measurement: An empirical analysis of poverty in Belgium, France, Germany, Italy and Spain, based on the European panel. Applied Economics 43: 951-61. [CrossRef]

Datt, Gaurav, and Dean Jolliffe. 2005. Poverty in Egypt: Modeling and policy simulations. Economic Development and Cultural Change 53: 327-46. [CrossRef]

De Alba, Iván Guillermo González. 2017. Poverty, Remoteness and Social Mobility of the Indigenous Population in Mexico. Oxford: University of Oxford.

De Silva, Indunil. 2008. Micro-level determinants of poverty reduction in Sri Lanka: A multivariate approach. International Journal of Social Economics 35: 140-58. [CrossRef]

Esquivel, Gerardo. 2015. Desigualdad Extrema en México: Concentración del Poder Económico y Político. Mexico City: Oxfam México.

Fernández-Ramos, Jennifer, Ana K. Garcia-Guerra, Jorge Garza-Rodriguez, and Gabriela Morales-Ramirez. 2016. The dynamics of poverty transitions in Mexico. International Journal of Social Economics 43: 1082-95. [CrossRef]

Fosu, Augustin Kwasi. 2017. Growth, inequality, and poverty reduction in developing countries: Recent global evidence. Research in Economics 71: 306-36. [CrossRef]

Garza-Rodríguez, Jorge. 2015. The Determinants of Poverty in Mexico: 2002 MPRA paper 65995. München: University Library of Munich.

Garza-Rodriguez, Jorge. 2018. Poverty and economic growth in Mexico. Social Sciences 7: 183. [CrossRef]

Garza-Rodriguez, Jorge, Martha Gonzalez-Martinez, Luz Solis-Santoyo, Marcela Quiroga-Lozano, and Gabriela Yarto-Weber. 2010. Chronic and transient poverty in Mexico: 2002-2005. Economics Bulletin 30: 3188-200.

González de Alba, Iván Guillermo. 2010. Poverty in Mexico from an Ethnic Perspective. Journal of Human Development and Capabilities 11: 449-65. [CrossRef]

Gounder, Neelesh. 2013. Correlates of poverty in Fiji: An analysis of individual, household and community factors related to poverty. International Journal of Social Economics 40: 923-38. [CrossRef]

Grootaert, Christiaan, and Deepa Narayan. 2004. Local institutions, poverty and household welfare in Bolivia. World Development 32: 1179-98. [CrossRef]

Gujarati, Damodar N., and Dawn C. Porter. 2009. Basic Econometrics, 5th ed. New York: McGraw-Hill.

Habyarimana, Faustin, Temesgen Zewotir, and Shaun Ramroop. 2015. Determinants of Poverty of Households in Rwanda: An Application of Quantile Regression. Journal of Human Ecology 50: 19-30. [CrossRef] 
Hao, Lingxin, and Daniel Q. Naiman. 2007. Quantile Regression (No. 149). Thousand Oaks: SAGE Publications, Inc.

Heshmati, Almas, Esfandiar Maasoumi, and Guanghua Wan. 2019. An analysis of the determinants of household consumption expenditure and poverty in India. Economies 7: 96. [CrossRef]

Hoffmann, Rodolfo, and Ana Lúcia Kassouf. 2005. Deriving conditional and unconditional marginal effects in log earnings equations estimated by Heckman's procedure. Applied Economics 37: 1303-11. [CrossRef]

Huesca, Luis. 2009. Análisis contrafactual del mercado de trabajo informal en la Frontera Norte de México. Equilibrio Económico 5: 5-28.

Instituto Nacional de Estadística y Geografía (INEGI). 2019. Encuesta Nacional de Ingresos y Gastos de los Hogares (ENIGH) 2018: Descripción de la Base de Datos. Available online: www.inegi.org.mx/contenidos/programas/enigh/nc/2018/doc/enigh18_ descriptor_archivos_fd_ns.pdf (accessed on 14 April 2021).

Iqbal, Asim, Anjum Siddiqui, and Maryam Zafar. 2020. A geographically disaggregated analysis of multidimensional poverty in Punjab. International Journal of Social Economics 47: 365-83. [CrossRef]

Islam, Deen, Jamil Sayeed, and Nazmul Hossain. 2017. On Determinants of Poverty and Inequality in Bangladesh. Journal of Poverty 21: 352-71. [CrossRef]

Jayathilaka, Ruwan, Saroja Selvanathan, and Jayatilleke S. Bandaralage. 2016. Is there a link between alcohol consumption and the level of poverty? Applied Economics 48: 2054-63. [CrossRef]

Jiménez Pozo, Wilson, Fernando Landa Casazola, and Ernesto Yañez Aguilar. 2006. Bolivia. In Indigenous Peoples, Poverty and Human Development in Latin America. Edited by Gillette Hall and Harry Anthony Patrinos. London: Palgrave Macmillan, pp. 40-66.

Kedir, Abbi. M., and Michael Henry. 2010. Neither Studying nor Working: Evidence on Jamaican Youth, Mimeo. Leicester: University of Leicester.

Kedir, Abbi. M., and Sandra Sookram. 2013. Poverty and welfare of the poor in a high-income country: Evidence from Trinidad and Tobago. Journal of International Development 25: 520-35. [CrossRef]

Koenker, Roger, and Gilbert Bassett. 1978. Regression Quantiles. Econometrica 46: 33-50. [CrossRef]

Lanjouw, Peter, and Martin Ravallion. 1995. Poverty and Household Size. The Economic Journal 105: 1415-34. [CrossRef]

Larrea, Carlos, and Fernando M. Torres. 2006. Ecuador. In Indigenous Peoples, Poverty and Human Development in Latin America. Edited by Gillette Hall and Harry Anthony Patrinos. London: Palgrave Macmillan, pp. 67-105.

Leeds, Michael A. 2014. Quantile regression for sports economics. International Journal of Sport Finance 9: 346-59.

Lekobane, Khaufelo R., and Tebogo B. Seleka. 2017. Determinants of Household Welfare and Poverty in Botswana, 2002/2003 and 2009/2010. Journal of Poverty 21: 42-60. [CrossRef]

Lerman, Robert I. 2002. Impacts of Marital Status and Parental Presence on the Material Hardship of Families with Children. In Urban Institute Working Paper. Washington, DC: The Urban Institute.

Lipton, Michael., and Martin Ravallion. 1995. Poverty and policy. In Handbook of Development Economics. Edited by J. Behrman and T. N. Srinivasan. Amsterdam: Elsevier, pp. 2551-657. [CrossRef]

Ogutu, Sylvester O., and Matin Qaim. 2019. Commercialization of the small farm sector and multidimensional poverty. World Development 114: 281-93. [CrossRef]

Ortiz Galindo, Jonathan, and Humberto Ríos Bolívar. 2013. La Pobreza en México, un análisis con enfoque multidimensional. Análisis Económico 28: 189-218.

Pearce, Diane. 1978. The Feminization of Poverty: Women, Work, and Welfare. Urban and Social Change Review 11: $28-36$.

Peng, Chenhong, Lue Fang, Julia Shu Huah. Wang, Yik Wa Law, Yi Zhang, and Paul S. F. Yip. 2019. Determinants of Poverty and Their Variation Across the Poverty Spectrum: Evidence from Hong Kong, a High-Income Society with a High Poverty Level. Social Indicators Research 144: 219-50. [CrossRef]

Ramirez, Alejandro. 2006. Mexico. In Indigenous Peoples, Poverty and Human Development in Latin America. Edited by Gillette Hall and Harry Anthony Patrinos. London: Palgrave Macmillan, pp. 150-98.

Ravindra Deyshappriya, N., and R. W. W. Minuwanthi. 2020. Determinants of Poverty: Is Age Non-Linearly Related with Poverty? Evidence from Sri Lanka. International Journal of Asian Social Science 10: 181-92. [CrossRef]

Rodrigues, Isabel Pereira, and Kittipong Rueanthip. 2019. Does being old mean being poor? Evidence from Thailand. DLSU Business and Economics Review 29: 165-77.

Rodríguez Pérez, Reyna Elizabeth, David Castro Lugo, and Montserrat Mendoza López. 2019. Desigualdad salarial y trabajo informal en regiones de México. Región y Sociedad 31: e1062. [CrossRef]

Sekhampu, Tshediso Joseph. 2013. Determinants of Poverty in a South African Township. Journal of Social Sciences 34: 145-53. [CrossRef]

Sen, Amartya. 1981. Poverty and Famines: An Essay on Entitlement and Deprivation: The Great Bengal Famine. Oxford: Oxford University.

Serratos, Luis. Adrian. 2015. On the Evolution of the Determinants of Household Poverty in Mexico: A Logistic Regression Analysis [Lund University]. Available online: http:/ / lup.lub.lu.se/luur/download?func=downloadFileandrecordOId=7511383andfileOId=75 11384 (accessed on 14 April 2021).

Shapiro, Joseph. 2006. Guatemala. In Indigenous Peoples, Poverty and Human Development in Latin America. Edited by Gillette Hall and Harry Anthony Patrinos. London: Palgrave Macmillan, pp. 106-49.

Székely, Miguel. 1998. The Economics of Poverty, Inequality and Wealth Accumulation in Mexico. In The Economics of Poverty, Inequality and Wealth Accumulation in Mexico, 1st ed. New York: St. Martin's Press. [CrossRef] 
Teka, Araya M., Gabriel Temesgen Woldu, and Zeremariam. Fre. 2019. Status and determinants of poverty and income inequality in pastoral and agro-pastoral communities: Household-based evidence from Afar Regional State, Ethiopia. World Development Perspectives 15: 100123. [CrossRef]

Todaro, Michael, and Stephen C. Smith. 2011. Economic Development. London: Pearson Education, Inc.

Troyano, Miguel Carrera, and Rafael Dominguez Martín. 2017. Poverty reduction in Brazil and Mexico. Growth, inequality and public policies. Revista de Economia Mundial 2017: 23-42.

Waite, Linda J. 1995. Does marriage matter? Demography 32: 483-507. [CrossRef]

Weaver, Robert D. 2012. Social Capital and its Role in Poverty Reduction: A Canadian-Based Analysis. Journal of Comparative Social Welfare 28: 57-74. [CrossRef]

White, Lynn, and Stacy J. Rogers. 2000. Economic circumstances and family outcomes: A review of the 1990s. Journal of Marriage and Family 62: 1035-51. [CrossRef]

World Bank. 2020. World Development Indicators. Available online: https://datacatalog.worldbank.org/dataset/world-developmentindicators (accessed on 14 April 2021).

Yamada, Takahiro. 2018. Dynamics of spatial inequality and poverty: Evidence from two decades of surveys in Vietnam, 1993-2014. Economics Bulletin 38: 404-18. 